\title{
O stylu (stylach) komentarzy internetowych
}

\author{
Elżbieta Laskowska \\ Uniwersytet Kazimierza Wielkiego w Bydgoszczy \\ laskowskae@poczta.onet.pl
}

\section{Streszczenie}

Przyjmując za punkt wyjścia istnienie stylów i gatunków tekstu, opisanych przez A. Awdiejewa $i$ G. Habrajska (2006), autorka próbuje określić, jakie cechy stylistyczne (ewentualnie też gatunkowe) maja komentarze internetowe na przykładzie komentarzy zamieszczanych na portalu Onet.pl. Obserwacja wykazuje, że badane teksty maja przede wszystkim potoczne wykładniki językowe, ale nie brak im też wykładników publicystycznych. Można zatem mówić o stylu mieszanym.

Słowa kluczowe: komentarze internetowe, wykładniki językowe, emocje, styl i gatunek tekstu

\section{Abstract}

On (style)s of internet commentaries

Assuming text styles and genres as described in Awdiejew and Habrajska (2006), in this paper I try to determine which stylistic (genre) features can be proposed for internet commentaries, basing on those placed in Onet.pl. The study shows that the analyzed texts have mostly typological indicators of colloquial style, but they also possess typological indicators of journalistic genres. We can thus propose the existence of mixed style.

Keywords: internet commentaries, linguistic indicators, emotions, style and text genre

\section{Sytuacja komunikacyjna komentarzy internetowych}

Internet jako nowe medium powoduje, że wiele tradycyjnych składników sytuacji komunikacyjnej (Laskowska 2010b) ulega przeobrażeniom. Weźmy pod uwagę sytuację komunikacyjną komentarzy internetowych. Chodzi mi o komentarze zamieszczane przez internautów na portalach zawierających bieżące informacje, np. Onet, Wirtualna Polska, Interia. Nadawcą komentarza nie jest profesjonalista, lecz odbiorca wiadomości, posługujący się jedynie nickiem, nieznany szerszemu ogółowi. Jedną z cech charakterystycznych 
komunikacji internetowej jest wszak to, że nadawcą może być każdy - w przeciwieństwie do tradycyjnych mediów (Laskowska 2010 a). Wypowiedź zamieszczona w Internecie ma odbiorcę zamierzonego i zbiorowego. Przyjmuję, że taki właśnie odbiorca jest właściwy dla dyskursu publicznego (Laskowska 2010 c). Kontakt w komunikacji internetowej jest pośredni, ponieważ nie ma tu relacji face to face, choć - z innego powodu - komentarze internetowe należałoby scharakteryzować jako potoczne. Będzie o tym mowa w dalszym ciągu. Tworzywem jest język pisany, choć wypowiedzi komentarzy internetowych mają wiele cech języka mówionego. W kontakcie bezpośrednim wypowiedzi towarzyszą gesty, mimika itp., w Internecie elementy zastępowane te są przez emotikony (Habrajska 2010). Dodajmy jeszcze, że komunikacja internetowa pozbawiona jest jedności miejsca. Co do czasu - może ona być niemal synchroniczna, a może też wypowiedź przechowywana bardzo długo (Habrajska 2010: $142-159)$.

\section{Styl i gatunek tekstu}

Nie ma tu miejsca na wszechstronne i wnikliwe rozpatrywanie istoty stylu i gatunku tekstu według różnych badaczy. Za Aleksym Awdiejewem i Grażyną Habrajską (2006:191) przyjmuję cel komunikacyjny jako kryterium wyodrębniania gatunków tekstu: „W tym ujęciu gatunek i styl w różny sposób wskazują na ten sam tekst i w tym zakresie można je utożsamiać. Gatunek jest określony przez cel komunikacyjny, a styl przez określone wykładniki” (Awdiejew, Habrajska 2006:191). Autorzy wyróżniają styl potoczny, którego „przeznaczeniem [...] jest organizacja bezpośredniej komunikacji face to face [..]”. Kolejny styl - naukowy ma na celu wspólne ustalenie prawdy. Styl urzędowy, mając siłę prawną, kodyfikuje stosunki społeczne. Celem tekstów publicystycznych jest perswazja. Teksty literackie mają na celu wywołanie przeżycia estetycznego odbiorcy (Awdiejew, Habrajska 2006: 190-193). Autorzy opisują także style mieszane (2006: 341 i nn.). Mają one więcej niż jeden cel komunikacyjny. I tak na przykład wiadomości (np. z Onetu) są dla badaczy przejawem stylu mieszanego - publicystyczno-naukowego (2006: 352). Komentarz jest natomiast traktowany jako wypowiedź publicystyczna (2006: 273). Już pierwszy rzut oka na komentarze internetowe pozwala zauważyć, że nie mają one tych samych cech, co komentarze, o których piszą autorzy „Wprowadzenia do gramatyki komunikacyjnej”. Można w komentarzach tych wprawdzie zauważyć funkcję perswazyjną, zastanawiam się jednak, czy jest to ich jedyna funkcja i - co więcej - jest to ich funkcja najważniejsza. Ponadto wykładniki językowe komentarzy internetowych mają charakter przede wszystkim potoczny. Dlatego 
chciałabym przyjrzeć się cechom stylistycznym i gatunkowym omawianych wypowiedzi. Na tym tle przydatne zdaje się wykorzystanie pojęcia rejestru, rozumianego jako sytuacyjnie uwarunkowane nacechowanie stylistyczne „W najwęższym sensie” (Bartmiński 1993). Przy takim ujęciu tradycyjny komentarz internetowy należy do innego rejestru niż komentarz prasowy i do innego rejestru niż rozmowa potoczna.

\section{Cechy języka komentarzy internetowych}

Komentarz internetowy jest repliką ${ }^{1}$, będącą reakcją na wiadomość, zamieszczoną na portalu, niekiedy też - reakcją na wypowiedź innego internauty (por. Habrajska 2010). Komentarze internetowe są pełne środków językowych nacechowanych wartościująco- emocjonalnie. Jest to cecha języka potocznego (Awdiejew, Habrajska 2006: 206-207). Środki te stanowią przejaw wyrażania ,subiektywnej ekspresywności mówiących, która [...] nie tylko wyraża stosunek emocjonalny do wyrażanych tematów, lecz tworzy odpowiednie podłoże psychologiczne i atmosferę, pozwalające na pełną samorealizację uczestników konwersacji” (Awdiejew, Habrajska 2006: 206). Nacechowanie ekspresywne jest także cechą wypowiedzi publicystycznych. Mają one charakter perswazyjny, służą powstaniu solidarności uczuć (Awdiejew, Habrajska 2006: 258). Popatrzmy na przykład: ${ }^{2}$

(1) Gimnazja są bez sensu. Ja (rocznik 88) w gimnazjum uczyłem się na kilku przedmiotach tego samego co w podstawówce, tylko wiedza była uzupełniana, a potem w liceum znów powtórka gimnazjum uzupełniana kolejnym materiałem. Tym sposobem nigdy nie poznałem dziejów 2 wojny światowej, bo nie można było dojść do tego okresu, za to 3 razy przerabiałem Mieszka I. I jak tu wiedzieć, co to jest kapitalizm, socjalizm itp. skoro to są nowoczesne ustroje? Ja wiem, co to monarchia i tyrania. $\mathrm{Z}$ angielskim też było powtarzanie, podobnie chemia, fizyka, geografia. Matematyka i informatyka to jedne z nielicznych wyjątków, gdzie był ciągle postęp i niewracanie do już poznanych zagadnień. Także jestem ZA likwidacją gimnazjów.

Przykład (1) stanowi opinię, która wyrażona jest w pierwszym zdaniu i powtórzona w ostatnim. Część środkowa to przesłanki uzasadniające opinię. Omawiana wypowiedź ma zatem cechy komentarza publicystycznego i za taki można by ją uznać, gdyby nie kolokwialne $J a$, użyte dwukrotnie, potoczne przerabiać oraz potoczność składni w wypowiedzeniu $Z$ angielskim też było powtarzanie, podobnie chemia, fizyka, geografia. Uznać zatem należy, że wypowiedź (1) ma językowe wykładniki stylu publicystycznego oraz potocznego. Oto inny przykład: 
(2) Dziś już praktycznie wszyscy wiedzą, że okrągły stół to układ!!! Solidaruchy mieli mieć władzę, a Komuchy biznes i media, z tym że Komuchy wiedzieli, że dzięki mediom mogą wcześniej czy później pozbyć się Solidaruchów, wystarczyło tylko poszperać, podstawić świnię a potem $\mathrm{w}$ swoich mediach, naginając fakty $\mathrm{i}$ rozpowszechniać jako prawdę. Dodatkowo Komuchy do Solidaruchów wcisnęli tysiące swoich agentów (przykład UKŁAD WROCŁAWSKI) którzy zaczęliby mieszać, gdyby Solidaruchy zaczęli się buntować.

Jeszcze więcej wykładników stylu potocznego ma przykład (2). Do wykładników tych należy słownictwo poszperać, podstawić świnię, wcisnać, mieszać. Zamiast cech prozodycznych, które zastosowane byłyby w prototypowych tekstach potocznych nadawca przykładu (2) użył potrojonego wykrzyknika (zastępnik podwyższonej intonacji) oraz wielkich liter (zastępnik akcentu logicznego). Charakterystyczna w tym przykładzie jest też potoczna składnia: Solidaruchy mieli mieć władzę, a Komuchy biznes i media, z tym że Komuchy wiedzieli, że dzięki mediom moga wcześniej czy później pozbyć się Solidaruchów ${ }^{3}$ [...]. Można zauważyć też konstrukcje słowotwórcze komuchy i solidaruchy, które są w jakimś stopniu w języku potocznym utrwalone, a ich negatywne nacechowane przejawia się $\mathrm{w}$ wykorzystaniu augmentatywnego formantu $-u c h$.

Konstrukcje słowotwórcze pojawiają się w komentarzach internetowych - podobnie jak w rozmowach potocznych jako - efemerydy (por. Awdiejew, Habrajska 2006: 198):

(3) Bredzisław Macierewicz [...]

(4) Jeśli sprawdzą się zapowiedzi dziadosława, że to ta propagandzistka ma objąć funkcję ministra sprawiedliwości $[\ldots]$

Bredzisław oraz dzialosław utworzone zostały na wzór imion, przy czym tylko znajomość sytuacji polityczno-społecznej pozwala na rozumienie związku pierwszego słowa ze słowem bredzić, a drugiego - ze słowem dziad ${ }^{4}$. Druga konstrukcja zapisana jest małą literą, nie jest jasne, czy ma to funkcję wartościującą, czy świadczy o braku znajomości zasad ortografii.

Podobny mechanizm towarzyszy innowacjom frazeologicznym:

(5) Wyjdziesz na tym jak Zabłocki na Stefczyku. 
Przykład (5) w sposób innowacyjny odnosi się do Kas Stefczyka. Nadawca modyfikuje frazeologizm wyjść na czymś jak Zabłocki na mydle, dzięki czemu omawiana modyfikacja ma - podobnie jak frazeologizm - nacechowanie negatywne, ale równocześnie wskazuje obiekt wartościowania. Ten sam obiekt przez innego internautę zostaje nazwany tak:

(6) Kasy fircyka po upadku nie wypłacą ci 50 groszy.

Tu mamy do czynienia z modyfikacją nazwy za pomocą wprowadzenia w miejsce drugiego członu nacechowanej negatywnie nazwy osobowej fircyk.

Jakkolwiek przykłady (5) i (6) traktuję jako przejaw potoczności, to nie zawsze w badanym materiale o nacechowaniu potocznym można mówić. W jednym z komentarzy na temat Łodzi pojawiła się następująca fraza:

(7) Nic co łódzkie nie jest mi obce.

Odwołanie się do znanej dewizy renesansu Nic co ludzkie, nie jest mi obce znamionuje raczej styl publicystyczny, a w każdym razie nie potoczny, jeśli trzeba byłoby wybierać między tylko tymi nacechowaniami stylistycznymi.

Nie brakuje w komentarzach internetowych wartościowania za pomocą ironii:

(8) Pani Szydło razem z PiSem dali radę:

- obnizyć wiarygodność finansowa Polski,

- osłabić złotówke o ok. 10\%,

- osłabić polityczna pozycję Polski w Europie i wywołać dyskusję w UE o demokracji $w$ Polsce,

- wyprowadzić na ulice setki tysięcy niezadowolonych z rządu Polaków,

- zablokować prace Trybunatu Konstytucyjnego,

- wprowadzić prawo pozwalajace na petna inwigilacje obywateli,

- przejąć media państwowe,

- obsadzić swoimi ludźmi stołki w firmach z kapitałem Skarbu Państwa,

- przyjąć prawo pozwalające praktycznie bez kryteriów, a jedynie z klucza partyjnego, obsadzać stanowiska $w$ administracji,

- przejać prokuraturę,

- wprowadzić nowe podatki pośrednio uderzajace w każdego z obywateli.

Brawo! 
Mamy tu do czynienia ze stylizacją na tekst naukowy, taka stylizacja właściwa jest raczej dla stylu publicystycznego niż potocznego. To $\mathrm{w}$ stylu naukowym spotykamy się często $\mathrm{z}$ wyszczególnianiem cech lub składników opisywanego zjawiska.

Nieprototypowość komentarzy internetowych jako wypowiedzi potocznych przejawia się w swoistym sygnalizowaniu elementów parajęzykowych. Na przykład:

(9) Dziękuję za tę nagrodę, którą odbieram od środowiska ludzi, którzy mnie wspierali. Byliście blisko mnie i w końcu wybraliście mnie na urząd prezydenta, a potem wybraliście w wyborach Prawo i Sprawiedliwość, żeby w Polsce mogła zaistnieć dobra zmiana - mówił prezydent, odbierając nagrodę.

ha ha ha ha ha ha ha ha ha ha ha ha ha ha ha ha ha ha ha ha ha ha ha ha ha ha ha ha ha ha ha ha ha ha ha ha ha ha ha ha ha ha ha ha ha ha ha ha ha ha ha ha ha ha ha ha ha ha ha ha ha ha ha ha ha ha ha ha ha ha ha ha ha ha ha ha ha ha ha ha ha ha ha ha ha ha ha ha ha ha ha ha ha ha ha ha ha ha ha ha ha ha ha ha ha ha ha ha ha ha ha ha ha ha ha ha ha ha ha ha ha ha ha ha ha ha ha ha ha ha ha ha ha ha ha ha ha ha ha ha ha ha ha ha ha ha ha ha ha ha ha ha ha ha ha ha ha ha ha ha ha ha ha ha ha ha ha ha ha ha ha ha ha ha ha ha ha ha ha ha ha ha ha ha ha ha ha ha ha ha ha ha ha ha ha ha ha ha ha ha ha ha ha ha ha ha ha ha ha ha ha ha ha ha ha ha ha

(10) Jak nakręceni kwik kwik kwik kwik kwik kwik kwik kwik kwik kwik kwik kwik kwik kwik kwik kwik kwik kwik kwik kwik kwik kwik kwik kwik kwik kwik kwik kwik kwik kwik kwik kwik kwik kwik kwik kwik kwik kwik kwik kwik kwik kwik kwik kwik kwik kwik kwik kwik kwik kwik kwik kwik kwik kwik kwik kwik kwik kwik kwik kwik kwik kwik kwik kwik kwik kwik kwik kwik kwik kwik kwik kwik kwik kwik kwik kwik kwik kwik kwik kwik kwik kwik kwik kwik kwik kwik kwik kwik kwik kwik kwik kwik kwik kwik kwik kwik kwik kwik kwik kwik kwik kwik kwik kwik kwik kwik kwik kwik

Wydaje się, że w porozumiewaniu się bezpośrednim emocje wyrażone za pomocą wielokrotnie powtórzonych ha oraz kwik nie miałyby takiej siły emocji, jaką mają w komentarzach internetowych.

Przedstawiłam tylko niektóre językowe wykładniki wskazujące na styl. Można stwierdzić, że komentarze internetowe mają wykładniki dwóch stylów: potocznego i publicystycznego, a zatem należałoby mówić o stylu mieszanym. 


\section{Cechy swoiste}

W komentarzach internetowych zauważam potoczny sposób myślenia:

(11) Zdumiewające jest to, jacy ci nasi politycy są "wielcy":) Od prawicy do lewicy. Jednak prawdą jest to, że nadmiar władzy przyczynia się do tego, że woda sodowa uderza do głowy. Każdemu politykowi. Nic dziwnego potem, że oderwanie ryja od koryta jest tak bolesne. Nagle trzeba z napęczniałego balonu ego spuścić powietrze. Przestać bujać w obłokach, ale zacząć pływać na powierzchni rzeczywistości. W chmurach klakierzy machają rękoma za polityka, a na powierzchni rękoma polityk musi machać sam. I to boli. Upadek z wielbionego cielęcia bryta na zwykłe cielę.

W przykładzie (11) mamy do czynienia z uogólnianiem 'każdemu politykowi uderza woda sodowa do głowy'. Teza ta traktowana jest jako prawda oczywista, która nie wymaga uzasadnień (por. Hołówka 1986: 25). Wyrażeniu tej oczywistości towarzyszą potoczne wykładniki językowe. Przykład (11) posiada jeszcze jedną cechę, która charakteryzuje komentarze internetowe. Jest to nacechowanie negatywne, wyrażane niekiedy w sposób dosadny - aż do stosowania wulgaryzmów. Oto jeszcze jeden przykład:

(12) I tak w kółko smoleńsk, wojny, wojenki, rozliczania czy ktoś zadba końcu o obywateli? Może widzę tylko czubek własnego nosa, ale ja chcę spokojnie żyć, tak jak żyją ludzie w cywilizowanych krajach. W D mam smoleńsk i święte wojny. Maciarewicz, spieprzaj z polityki, zrób miejsce dla młodych, którym życie miłe; wrak tupolewa postaw sobie w ogrodzie, zbuduj ławkę i spotykajcie się tam z Kaczyńskim porozmawiacie sobie o agentach spiskach itd.

Temu sposobowi wyrażania emocji często towarzyszy agresja:

(13) Proś Polaków o wybaczenie, oddaj Nobla i zniknij raz na zawsze z życia publicznego, pogrążony we wstydzie. Kiedyś broniłem Cię własną piersią, ale gdy zorientowałem się, że jesteś tępym, nadętym i sprzedajnym bufonem oraz kłamcą stałeś się dla mnie zdrajcą. Wspominałem Twoją osobę z obrzydzeniem. Dziś okazało się, że moje wnioski były słuszne. Nic i nikt tego nie zmieni, a im mniej będę Cię widywał w mediach, tym lepiej dla Ciebie i historii Solidarności.

(14) Apel do tych świń oderwanych od koryta. Do frustrowanych frajerów którzy skaczą na marszach KOD jak psychiczni. Także do tych kapuścianych łbów, którzy właśnie trzęsą portami ze strachu, bo TVN powiedział im, że pod rządami PIS wszystko się zawali.

Wy naprawdę już nic nie umiecie i nie potraficie znaleźć innego sposobu na życie niż 
trwanie przy korycie? Nie macie honoru? Powinniście się pogodzić się z przegraną, a wy wciąż kwiczycie, skamlecie, płaczecie... żal mi was, głupie ciule. Chcieliście demokracji, wybraliście PIS, no to niech rządzi... Najmijcie się do śniegu, bo akurat zima jest. Macie jeszcze szanse coś dobrego zrobić dla tego kraju.

W tego typu wypowiedziach reprezentowane są różne poglądy polityczne. Nie ma jednak związku między opcją polityczną a sposobem wyrażania emocji: agresja jest w wypowiedziach zwolenników różnych opcji politycznych. Agresja nie musi zresztą towarzyszyć ocenom politycznym:

(15) co fircyku, beztalencie, mama cię utrzymuje, płaci za internet, a masz tyle kasy co brudu za brudnymi pazurami.

Tak zwraca się internauta do innego internauty, nadawca wie prawdopodobnie o odbiorcy tego komentarza tylko tyle, że wypowiadał się w Internecie.

Zauważyć można, że wulgaryzmy i agresja są cechami charakterystycznymi dla komentarzy internetowych. W typologii gatunków tekstu cechy te się nie mieszczą. Wulgaryzmy i agresja nie są wyznacznikami żadnego stylu - chciałoby się powiedzieć. A jednak zjawiska te istnieją. Teresa Skubalanka, pisząc o stylach: wysokim, średnim i niskim, mówi, że osoby używające wulgaryzmów są „w stanie niezwykłej emocji” lub też osoby te „nie umieją panować nad sposobem wysłowienia, nierzadko są to osobnicy ordynarni i prostaccy” (Skubalanka 1969: 13). Czy zatem osoby piszące komentarze internetowe należą do marginesu społecznego? Chyba nie, bo wtedy margines ten byłby tak szeroki, że przestałby być marginesem. Wydaje się, że stworzyła się swoista moda na zachowania agresywne i wulgarne, która w komentarzach internetowych ma swój ekstremalny wyraz. Sprzyja temu zapewne anonimowość wypowiedzi internetowych, chociaż zjawiska, o których mowa, spotykamy też w mediach tradycyjnych (por. Satkiewicz 2000: 28, Mosiołek - Kłosińska 2000: 112).

\section{Komentarze internetowe jako nowy gatunek tekstu czy nowy rejestr?}

Omawiając styl potoczny Awdiejew i Habrajska (2006): 194 i nn.) piszą o prototypowej komunikacji potocznej (jedność miejsca i czasu, kontakt face to face) oraz o komunikacji nieprototypowej. Przyjmuję, że komentarze internetowe stanowią przejaw komunikacji potocznej. Biorąc pod uwagę tworzywo, którym jest pismo, a nie mowa, można przyjąć, że 
komentarze te podobne są do prywatnych listów (tradycyjnych i elektronicznych) oraz smsów. Ponadto nieistotna jest kwestia jedności miejsca i czasu. I wreszcie celem komunikacyjnym rzadko jest organizowanie wspólnego działania interlokutorów ${ }^{5}$. Pisząc o stylu publicystycznym, przywoływani autorzy (2006: 256 i nn.), zwracają uwagę na różnorodność tekstów publicystycznych. Wydaje się, że można by analogicznie mówić nie tyle o nieprototypowości komentarzy internetowych jako tekstów nie tylko potocznych, ale także publicystycznych, ile o przynależności komentarzy internetowych do innego rejestru niż komentarze publicystyczne oraz do innego rejestru niż list prywatny. Przyjmując, że omawiane wypowiedzi należą do stylu mieszanego - potoczno-publicystycznego, można by zastanowić się, czy dotychczasowy opis odmian stylistycznych nie wymaga pewnych uzupełnień, które wynikają z istnienia współczesnej komunikacji odbywającej się za pomocą nowych mediów. Skłania mnie do tego refleksja nad celem komunikacyjnym komentarzy internetowych.

Pisząc o perswazji jako zasadniczym celu komunikacyjnym dla stylu publicystycznego, Awdiejew i Habrajska (2006: 264), mówią o ramie perswazyjnej, polegającej na kreowaniu wizerunku nadawcy i odbiorcy. Wizerunek nadawcy ma wzbudzić zaufanie u odbiorcy, wizerunek odbiorcy ma go dowartościować, co osiąga się przez komplementowanie. Ostatnią z wymienionych cech trudno odnaleźć byłoby w komentarzach internetowych. Odbiorca nie jest komplementowany, ale atakowany, podobnie jak osoby trzecie, do których odnoszą się komentarze internetowe. Czy nadawca liczy, że przekona do swoich poglądów odbiorcę, którego deprecjonuje? Czy liczy na wykreowanie wizerunku samego siebie, jeśli posługuje się wulgaryzmami? Jeśli by na te pytania odpowiedzieć przecząco, to jak miałaby się realizować funkcja perswazyjna komentarzy internetowych? Używając stylu niskiego, nadawca zapewne nie zamierza nikogo przekonywać. Może chce użyć Internetu w funkcji katarktycznej, wyrzucając $\mathrm{z}$ siebie złe emocje? Tak bywa w komunikacji potocznej, ale przecież nie to jest w niej najważniejsze.

Jeśli komentarze internetowe mają nie do końca cele właściwe dla odmiany publicystycznej i nie do końca - cele właściwe dla odmiany potocznej, a tylko wykładniki językowe w nich używane charakterystyczne są dla omawianych stylów, to może trzeba by wyróżnić nie tyle styl internetowy, ile rejestr internetowy, a może raczej rejestry internetowe, $\mathrm{w}$ jednym z nich sformułowane są wypowiedzi przeze mnie omawiane.

\section{Przypisy}

\footnotetext{
${ }^{1}$ Replikę rozumiem jako intencjonalnie nieprzerwaną wypowiedź jednego nadawcy.
} 
${ }^{2}$ Wszystkie podane przykłady pochodzą z komentarzy do tekstów, zamieszczonych na portalu Onet.pl 10 października 2015, 1 lutego 2016 i 19 lutego 2016. W przykładach poprawiłam jedynie literówki oraz błędy ortograficzne i interpunkcyjne.

${ }^{3}$ Nie jest jasne, dlaczego solidaruchy i komuchy autor tekstu pisze wielką literą.

${ }^{4}$ Jest to nawiązanie do słów Lecha Kaczyńskiego $s . . . . j$, dziadu.

${ }^{5}$ Dotyczy to komentarzy internetowych, a nie innych sposobów komunikowania się za pomocą Internetu.

\section{Bibliografia}

Awdiejew Aleksy, Grażyna Habrajska (2006) Wprowadzenie do gramatyki komunikacyjnej.

Tom 2. Łask: Oficyna Wydawnicza Leksem

Bartmiński Jerzy (1993) „Styl potoczny.” [W:] Jerzy Bartmiński (red.) Współczesny język

polski. Lublin: Wydawnictwo UMSC; 15-134.

Habrajska Grażyna (2010) „Język w Internecie.” [W:] Elżbieta Laskowska, ks. Mariusz

Kuciński (red.) Internet a relacje międzyludzkie; 142-159.

Hołówka Teresa (1986) Myślenie potoczne. Warszawa: PIW.

Laskowska Elżbieta (2010 a) „Internet - wyznaczniki nowej kultury?” [W:] Halina Bartwicka

(red.) Język, tekst, kultura Bydgoszcz: Wydawnictwo Uniwersytetu Kazimierza

Wielkiego; 261-269.

Laskowska Elżbieta (2010 b) „Niektóre składniki sytuacji komunikacyjnej.” [W:] Grażyna

Sawicka (red.) Sytuacja komunikacyjna i jej parametry. I monografia z cyklu Sytuacje-

komunikacja - konteksty, Bydgoszcz: Wydawnictwo Uniwersytetu Kazimierza

Wielkiego; 70-76.

Laskowska Elżbieta (2010 c) „Style dyskursu publicznego”. [W:] Barbara Bogołębska,

Monika Worsowicz (red.) Styl, dyskurs, media. Łódź: Wydawnictwo UŁ; 179-186.

Mosiołek - Kłosińska Katarzyna (2000) „Wulgaryzacja języka w mediach”. [W:] Jerzy

Bralczyk, Katarzyna Mosiołek - Kłosińska (red.) Język w mediach masowych.

Warszawa: Upowszechnianie Nauki - Oświata "UN-O"; 112-119.

Satkiewicz Halina (2000) „Językowe przejawy agresji w mediach”.

[W:] Język w mediach masowych, red. Jerzy Bralczyk, Katarzyna Mosiołek - Kłosińska,

Warszawa: Upowszechnianie Nauki - Oświata "UN-O"; 28-33.

Skubalanka Teresa (1969) „Rola języka mówionego i pisanego”. [W:] Język polski.

Poprawność, piękno, ochrona, red. Stanisław Urbańczyk, Bydgoszcz: Bydgoskie

Towarzystwo Naukowe. 9-18. 